DÁNIEL OROSS - DÁNIEL RÓNA - ANDREA SZABÓ ${ }^{1}$

PATTERNS OF CIVIC PARTICIPATION AMONG POLITICALly ACTIVE STUDENTS IN HUNGARY

DOI: 10.18030/SOCIO.HU.2017EN.71

\title{
ABSTRACT
}

The article aims to describe common characteristics of politically active college and university students in Hungary and to give an insight into their divergent values, ideologies and motivations. First, we identify their participation in different forms of political action. Then we use a "phenomenological", intrinsic approach that is able to understand the "voice" of young people based on the suggestions of former research that young people's political communities influence their willingness to participate. We found that direct forms of participation are the key to understanding the political participation of the university students and we conclude that their political way of thinking and their consequent political action may be determined by three political communities in the long term.

Keywords: political participation, young people, political identities

1 Dániel Oross, PhD, political scientist, Hungarian Academy of Sciences Centre for Social Sciences, Junior Research Fellow. Dániel Róna, PhD, Political scientist, Corvinus University of Budapest, Institute for Political Sciences, Assistant Professor. PostDoctorate Researcher of the Hungarian Academy of Sciences. Andrea Szabó, PhD, Political scientist, Sociologist, Hungarian Academy of Sciences Centre for Social Sciences, Senior Research Fellow. 


\section{PATTERNS OF CIVIC PARTICIPATION AMONG POLITICALLY ACTIVE STUDENTS IN HUNGARY}

\section{INTRODUCTION}

This article investigates the political activity of Hungarian college and university students. Members of this age cohort are embedded both in the traditional values of their families and in the new ideas of youth organizations, and are therefore very sensitive to societal changes. Students' views on democracy are primarily shaped by the contemporary institutions that play a key role in the political socialization of youth (e.g. family, school, peer groups and the media). In 1989/90, following the democratic transition of the country, these institutions had to face new challenges and play new roles. The specificity of the Hungarian case is that a fragmented, semiperipheral political socialization became characteristic (Laki-Szabó A. 2014: 40-41) in which the role of these institutions in transferring democratic values to young people is not clarified. Even though the new system is different both institutionally and functionally from the previous one, and despite the current system being the antithesis of the previous system ideologically (Szabó I. 1994: 62-63) institutions within a fragmented, semiperipheral political socialization are unable to prepare students for the requirements of democratic citizenship; and certain patterns from the former, communist period and of earlier revolutive socialization persist.

We aim to explore the motivations of politically active college and university students from two different perspectives. On the one hand, we use the basically normative concept of political participation, which considers participation as a cornerstone of democracy and as such a socially desirable activity. On the other hand, we adopt a phenomenological perspective on politics which allows passivity as a "normal state" for young people and considers political activity as something unusual, which should be understood from the perspective of their actual activities. Former research suggests that although young Hungarians show indifference toward politics, ${ }^{2}$ if they encounter a social problem that closely affects them, they will stand up for their rights. We use two approaches in order to seize the political communities, groups that can mobilize, and articulate the political opinion of young people at the collective level. At the individual level, a participatory approach sets the dimensions along the political activity that can be described within a sample of Hungarian college and university students. The phenomenological approach groups students and explains the collective identities (e.g., passive, active, loyal and rebellious students) along which their activity can be described. By finding those groups that can offer a collective consciousness, or community spirit to active young people, it becomes possible to adequately describe actual processes that characterize the political activity of university students as a distinguished group of Hungarian youth.

2 Sociological studies conducted recently in Hungary unanimously suggest that youths' level of political interest strongly shapes their assessment of the political system, their acceptance of political actors, and also the modes with which they become integrated into society. The past 10-15 years of data collection pertaining to political socialization and voter behaviour have also shown a tendency in the population to turn away from politics (Szabó A. 2013: 21-26). 
Our paper consists of four main parts. First, we will review the literature of political participation and empirical studies on the political activities of the Hungarian youth. After the main forms of participation have been distinguished, we will go on to investigate the applicability of these forms to the current Hungarian political context. The next step is based on a university and college student survey conducted in 2013, and will include cluster-analyses which will pinpoint the main political community groups of the Hungarian youth. Finally, main findings and consequences will be discussed.

\section{THE LITERATURE OF POLITICAL PARTICIPATION}

By using the participation approach, we aim to highlight that within western democracies there is a long tradition of political participation assuming many different forms. While in previous decades there has been a clear decrease in traditional forms of political participation (voting, participation in political organizations, connection to political institutions), in Western Europe, other indicators show an increase in issue-driven civic participation among citizens (Dalton 2008, Inglehart 1997, Norris 2002, Norris-Curtice 2008, KlingemannFuchs 1995, Pattie et al. 2004, Kriesi 2008, Dalton 2004, McAdam-McCarth-Zald 1996). In other words, voting, campaigning, and participation in political parties may have become unpopular, but participation in protests and in citizen lobby groups has clearly become more popular. While some researchers have interpreted these trends as reflecting growing scepticism and apathy (Henn-Weinstein-Wring 2002), others have called attention to the danger inherent in formulating oversimplified claims such as "the youth have become disillusioned with politics" (Zukin et al. 2006: 118-189). It may well be the case that the upcoming generations are simply interested in inventing novel forms of political participation (Phelps 2004).

Twenty-five years ago in Hungary, at the start of democratic transition, there appeared a myriad of new forms of political participation within post-socialist Hungarian society. Concerning East-Central Europe and Hungary, there have been few studies referring to these changes in participation patterns. The most significant Hungarian research program of the last two decades focusing on youth and politics, "Ifjúság" (Youth) repeated every four years, 3 concluded that young Hungarians are passive and apolitical, more so than their western European peers (Szabó A.-Bauer-Laki 2002, Bauer-Szabó A. 2005, Bauer-Szabó A. 2009, Oross 2013). However, our approach is similar to the views of Edward Phelps (2004): we need to go beyond investigating young people's level of participation; there is a need to better understand the reasons for their activity and passivity since, in the 21st century, the validity of the democratic, normative approach has faded away. We think that a "phenomenological" approach is needed: an internal, intrinsic approach that is able to understand the "voice" of young people.

For decades now, Hungarian society - in international comparisons - has been noted for its apathy and low levels of civic participation and activism (Szabó A.-Bauer-Laki 2002 Bauer-Szabó A. 2005, Bauer-Szabó A. 2009, Oross 2013). Regarding the level of formal organization among Hungarian youth, former studies (e.g., the Ifjúság studies) unanimously describe the current youth cohort as a disorganized, fragmented generation. All of the research showed, however, that among the youth, those in university and college form an exception

3 Ifjúság is based on a large-scale sample survey conducted in everey four year since 2000. (N=8000) (Szabó-Kern 2011, Oross 2013) 
to the general rule. They are the ones who are relatively more active, of whom a relatively large proportion (e.g. 55\% of those studying at university) have some form of organizational affiliation (Szabó A.-Kern 2011: 69). Recent studies have shown that interest in public life and the willingness to be politically active has grown in certain groups (Szabó-Oross 2012). These groups, however, are not always committed to democratic values, i.e., growing civil society activism is strengthening antidemocratic processes as much as democracy itself (Róna-Sörés 2012). We examine this dilemma from the approach of youth groups and their unequivocal interest in the far-right, but we also consider another group of active youth as well, who are situated outside the current political palette, have postmodern values, and revere solidarity.

There are moments that call into question the apolitical and passive Hungarian youth. In the fall of 2011 , in the winter of 2012, and then in the fall of 2014, university groups mobilized mass demonstrations that took place in Budapest and in the country's major cities-even in western European cities-which radically contradicted the well-known apolitical stereotypical image. However, the impact of these events on Hungarian college and university students cannot be detected by a participation approach, or by the traditional theory of democratic political participation. According to Williams, there is a need for an additional application of a theory and a methodology, which makes it easier to understand the importance of such unique participatory forms. In the United States, much research attention was drawn to culture as an area in which the change of action takes place, and sociologists dealing with protests and movements became interested in the consequences of these changes (Williams 2004). American social scientists started to investigate the recruitment, retainment, motivation and mobilization of members of social movements by using theories of collective identity and the theoretical framework of symbolic interactionism. The forerunners of US researchers' intellectual movement were authors of the German phenomenological sociology, Alfred Schütz who worked mainly in the 1940s, and the foraging theory of symbolic interactionism (Erving Goffman, Harold Garfinkel). These researchers dealing with social movements were not simply interested in participation and they not only tested different forms of it, but also considered the broader external, "cultural environment" and the narrower internal "internal" dimensions of movement culture (Williams 1995) that surrounded them. Accordingly, the static structural models were replaced by the investigation of dynamic and interrelated mechanisms and processes when analyzing the transition to the new forms of participation at the millennium. The great researchers of social movements, such as McAdam, Tarrow and Tilly began to increasingly test the processes, the actors/activists and their collective identities (della Porta-Tarrow 2005). The works of Gamson represent a particularly important addition to the participatory approach, highlighting three elements in understanding to the motivation to act: "injustice," "agency" and "identity". These help activists and organizers to understand the problems and dilemmas and to explore the ways in which social grievances trigger actions.

According to Williams (2004), it is important to investigate collective identities of young people, or more properly speaking, to examine their collective political thinking. We claim that the description of different forms of political participation is important and indispensable, but such an analysis has a rather static nature. The dynamic approach in this case means to seek and reveal the collective political communities that offer collective consciousness, identity, attachment, thinking ("collective behaviour") to young people, promoting the formation of political action (participation): those kinds of political actions that are sometimes broken 
up with overwhelming force and then fade completely. These one-time events (2011, 2012, 20104) can be considered as momentary rebellions, a point at which the lurking deep dissatisfaction breaks up. It is thus worth addressing the character of the rebellion thoroughly.

When using the term "rebellion," we first refer to what Antony Downs meant when he used the term "rationality". Rationality, here, meant that an individual "moves toward his goals in a way which, to the best of his knowledge, uses the least possible input of scarce resources per unit of valued output" (1957). Downs combined the rationality axiom with a self-interest axiom, so that rational behaviour, in his model, indicated "rational behaviour directed primarily toward selfish ends" (1957: 27).

The second part of the term "rebellion" is rooted in the notion of "postmodern riot". According to Máté Szabó, postmodern riot is - unlike modern protests which were homogeneous, "combined issues" characterized by one common issue and loose claims; however, participants formulate them along diverse, informal, spontaneous choices. The events have a central spine, but the implementation is much more diverse than it was at any time in history. Moreover, where appropriate, the central claim is carried simultaneously by traditional movements (unions), by new social movements (feminists) and by postmodern movements (such as anarchists) (Szabó M. 2008). The riot can be violent, of course, but violence is not the target; it is not the violence that is a characteristic feature of the term Szabó chooses, but eclecticism, diversity and coexistence are (Szabó M. 2007: 186-187). Connected to an issue (such as the anti-globalization protests in Seattle), activists with different perspectives, religions, ideologies, and languages get together, but it is likely that they never meet each other again. There is a single goal, which young people with different views, ideologies who are choosing a subtopic out of a set of issues and claims sympathetic to them can take up. Once a claim is embraced, they stand up for it in proportion to their self-interest, but they never act together again

Thirdly, we use the term "rebellion" as a characteristic of young Hungarians' political behaviour. Although young Hungarians are passive and not interested in politics, if and only if they face a political issue that affects them very much, their most active groups make their voices heard (e.g. at the end of the year 2012 when the government introduced restrictions within the higher education system). Their actions are very diverse and innovative, in some cases even loud and expressive, and they are not anti-democratic. Rebels are basically democratically-minded and approve of the capitalist market-economy, but they are critical (in some cases extremely critical) toward the existing Hungarian versions of those systems. They stand up because of an issue and after doing so, they return to their everyday lives (from which they try to exclude politics as much as possible). Moreover, there are many of them who are just "free-riders" and who think mostly about their own interests. The notion of rebellion explains the attitudes of the Hungarian youth; it puts into context their level of political activity (or rather their lack of it). We call these groups "rational" because their actions are primarily determined by self-interest. "Rebellion" refers to their high degree of dissatisfaction not just with the political elite, but with the political system as well (Szabó A. 2014).

The root of this is basically a passive behaviour originating from socialization mechanisms. In new and re-established democracies, "automatic" transmission of democratic values from one generation to the next cannot be taken for granted (Niemi-Hepburn 1995: 9). In Hungary, neither the most important agent 
of socialization, the family, nor the most important institutional agent, school, orient young people toward participation (Csákó 2011). As mentioned above, family members raised during the decades of state socialism learned passive patterns of participation, and apart from a short period of euphoria following transition, the new regime did not require particularly high levels of activity from them either. Families had permanent economic problems: poverty, mass unemployment, social leveling. Compared to these issues, a participationcentric socialization function was not considered important. Nevertheless, the Hungarian school systems still did not manage to teach democratic civic education, and Western European and German solutions remain unadopted. Hungarian schools are still highly hierarchical and conservative. In terms of civic education, the educational system is inconsistent and incomplete. Since the process of the political socialization in Hungary encodes passivity into young Hungarians, political passivity can be considered as the "normal state" for young people: in the last three decades, there has been little change in this field (Csákó 2004: 2011).

Clearly at this point, political activity and passivity, as well as political preferences, can be explained from different aspects and the results can also be different. This chapter first considers the normative political participation approach, then it considers the results from the aspect of the phenomenological approach of rebellion. Finally, we will elaborate on political preferences.

\section{DATA AND METHODS}

The emergence of novel forms of participation presents a theoretical challenge, prompting researchers to come up with new concepts and distinctions. One such innovation has been the separation of the "political" and "civic" forms of participation. (Dahlgren 2000, Dalton 2004, de Vreese 2006, Dunleavy 1996, LivingstoneBober-Helsper 2005, O'Toole et al. 2003, Phelps 2004, Verba et al. 1995). Other salient theoretical attempts include: Banes and Kaase's (1979) distinction between "traditional" and "non-traditional" forms of participation, Inglehart and Catterberg's (2002) focus on "elite-driven" and "anti-elitist" mobilization, Norris' (2002) "citizenoriented" and "case-oriented" participation, and Dalton's "responsibility-based" and "commitment-based" participation.

These different attempts at conceptualization have engendered an emerging methodological consensus according to which research focusing on explaining political participation should seek to group different forms of participation into statistical clusters. We draw on this analytical tool, as well as on Verba, Scholzman, and Brady's advice (1995) to approach the explanation of participation through a focus on resources as key conditions of existence.

Under the term "traditional forms of political participation" we subsumed participation at elections and participation in political organizations (political parties, unions), as well as forms of participation related to these organizations (such as campaigning, participation at meetings, wearing the symbols of these organizations, etc.). Direct forms of political participation comprise forms of participation that require personal involvement but do not require long-term commitment on behalf of the actor. We further distinguish between face-toface activities that require significant resources and intensive involvement from activities that do not require these. Examples of the former subtype include direct forms of protest such as sit-ins, blockades, expressive and 
symbolic acts (such as hunger strikes). Direct forms of political participation that require few resources come with a low risk and require low levels of commitment include the signing of statements, petitions and initiatives. Online participation appeared after the Internet broadened the forms of participation, enabling people to take part in political and public life virtually, in addition to both traditional and collective forms of participation. It became possible to take part in both traditional forms of political participation (e.g. campaigning) and direct forms (e.g. boycotts, petitions) through blogging, posting, and other forms of social-media use. This new form of participation typically requires low levels of commitment and few resources. ${ }^{4}$

The survey was of our own making and was conducted in the spring of 2013 using online and face-toface interviews with Hungarian university and college students. The survey was conducted with a so-called hybrid technique: 859 persons (66\%) filled out the online survey at hwww.aktivfiatalok.hu, while another 441 persons (34\%) were asked to answer questions via face-to-face interviews. The online survey was advertised by the universities: each student received an invitation to fill out the questionnaire by mail. Face-to-face interviews took place between 11th and 25th of April 2013 in all major institutions across the country (35 institutions). The sample contains 1,300 university and college students. The distribution of the sample reflects the distribution of the entire student population regarding gender, level of education (B.A. or M.A.), and faculty affiliation. 5 We have chosen the cluster analysis method.

Why is statistical cluster analysis, based on mathematical foundations, regarded as an internal, inherent method, rather than any other method? This method undoubtedly has a statistical basis, but based on the phenomenological approach, it includes a much wider range of variables than the participation approach. We are looking for "internal" dimensions based on Williams and Gamson approach that can reveal the political community, the collective consciousness that offers identity and bonds for young people, and frame the way in which they think, and promote political participation.

\section{RESULTS: FROM POLITICAL PARTICIPATION TO REBELLION}

When examining the connections between different forms of political participation, our results based on the data of Active Youth Research in 2013 show (see Figure 1) that direct forms of participation are the most dominant; almost three-quarters of students participated in some form of direct activity. This means that to understand Hungarian college and university students' participation, it is vital to closely examine these forms of participation; $19 \%$ of the students reported participating in traditional forms of political activities, while the ratio of those who claimed to participate in on-line activities was significantly below our expectations. Only $17 \%$ claimed to have done so. We summarized our results in an aggregated diagram, which is presented below. It is very rare that students participate in only one form of listed activity (fewer than $10 \%$ of all cases). If a student is at least occasionally active in one form of activity, s/he is likely to be active in other forms, too.

4 For definitions of the different forms of political participation are defined in a former publication, see: Szabó Andrea (ed.) Political Orientations, Values and Activities of Hungarian University and College Students, p.82, Prague: Heinrich Böll Stiftung, 2013. www.boell.de/sites/default/files/ political_orientations_final.pdf

5 Thus, the face-to-face interviews complemented the online part of the fieldwork. Interviewers visited the faculties and campuses with proportionally fewer online respondents. 
Figure 1. Political participation of Hungarian university and college students

$19 \%$

Traditional

forms of

participation

$17 \%$

Online forms of

participation

$32 \%$

Either not active in any sense, or there is no data available

$74 \%$

Direct forms of participation

Three-quarters of students (74\%) took part in direct forms of political participation. The most popular form of direct political participation was boycotting: $36 \%$ of students claimed they have boycotted before. About $30 \%$ of students participated in protests, and close to the same proportion engaged in some form of petition or political statement signing. Though spontaneous protests are a new form of demonstration in Hungarian society, they have already become the sixth most popular form of demonstration among Hungarian youth (16\% of respondents have taken part in spontaneous protests). Those enrolled in the social sciences or arts departments and those in religious studies showed the greatest willingness to partake in direct political activism.

Though the Internet has spread to almost 100\% of Hungarian college and university students, contrary to our hypothesis, virtual activism is not as prominent as expected. Virtual participation plays a complementary role and does not substitute for traditional or direct forms of participation. Our 2013 research strengthens our previous claim that virtual participation does not encourage previously passive individuals to partake in public affairs and politics.

The 2012 student protests against the Orbán government's higher education decisions resulted in an especially interesting overlap between the members of the virtual and direct forms of political participation (9\% of the examined population). The correlation between direct participation and virtual participation is strong: the model predicts that an individual participating in one additional type of off-line activity will be on average 1.456 times as likely to have partaken in a form of virtually-organized demonstration. Online activity (news clicks, blogs, page likes) in and of itself is not correlated with participation in virtually-organized protests and demonstrations. The area overlapped by all three forms of political participation (active youth) in our sample consisted of only $6 \%$ of respondents. This population represents those youths who actively engage in all three forms of political participation.

$32 \%$ of the surveyed students distanced themselves from all forms of political activity (or the data on them was not adequate) and were thus passive. ${ }^{6}$

6 For a more detailed explanation of the key findings of the different forms of political participation see a former publication: Szabó Andrea (ed.) Political Orientations, Values and Activities of Hungarian University and College Students, p82, Prague: Heinrich Böll Stiftung, 2013. www.boell.de/sites/default/files/political_orientations_final.pdf 
The second approach to understanding Hungarian university and college students' participation is the phenomenological approach that analyzes the topic from the perspective of young people. Former research (Utasi 2010) suggests that young people's political communities influence-albeit indirectly-their willingness to participate. In our view, political participation is not a key issue for university and college students, but they are interested in finding out for themselves whether it appeals to them, as part of the broader process of forming their identity and finding community. We intend to identify these political communities because it is believed that these are the groups that form the foundations of their rebellion.

Having discussed participation, we shall now turn to political preferences of the youth. For that, Hungary needs to be put in an international perspective first. Are young citizens over-represented in Europe among the supporters of far-right and green parties, or is it a Hungarian peculiarity?

\section{The result of cluster analyses}

In order to identify active and passive university and college students, we ran a K-Means cluster analysis, first with variables that did not include any political parties, but where the activity and ideological character of the young people was clearly identifiable. Then, we performed analysis with the involvement of Hungarian parties. Out of the great number of clusters ran, we have selected two that best fitted the student population. Correlation between the two clusters is high (Cramer's $V=0.652$ ). Our present analysis relies on the cluster model in which the parties were also involved.

Via cluster analysis, we analyze political attitudes, ideological orientations of college and university students related to different dimensions of political community. Via cluster analysis, we could identify 7 groups of Hungarian university and college students.

1. The biggest cluster of college and university students is the cluster of Apolitical, passive (37\%) students (see in the middle of Figure 2 and Figure 3). While the other clusters have some political features, some variables that allow for further description, this cluster cannot be well characterized along political dimensions. Those who are in this cluster do not particularly care what kind of political system they live in. Additionally, they are unsure as to whether they want to vote in the upcoming parliamentary election and, if they do want to vote, they are uncertain about which party to vote for. The most important feature of the members of the cluster is therefore political passivity, which is reflected by all forms of their participation and by their relationship toward the parties (mostly by keeping their distance). One element binding those in this cluster together is their loose identification with the label "green". However, since they are completely passive and disinterested in social and political issues, this identification does not mark an ideological commitment to "green politics". It perhaps also marks a loose identification with healthy eating, organic foods, selective waste-management and other superficial elements of the "green consumerist" lifestyle that are in vogue in Budapest. Because of their lack of interest in politics, these students are just drifting along with political events; their political activity is negligible. 
Figure 2. Hungarian university and college students' cluster map on a Left-Right and Moderate-Radical Scale (averages)

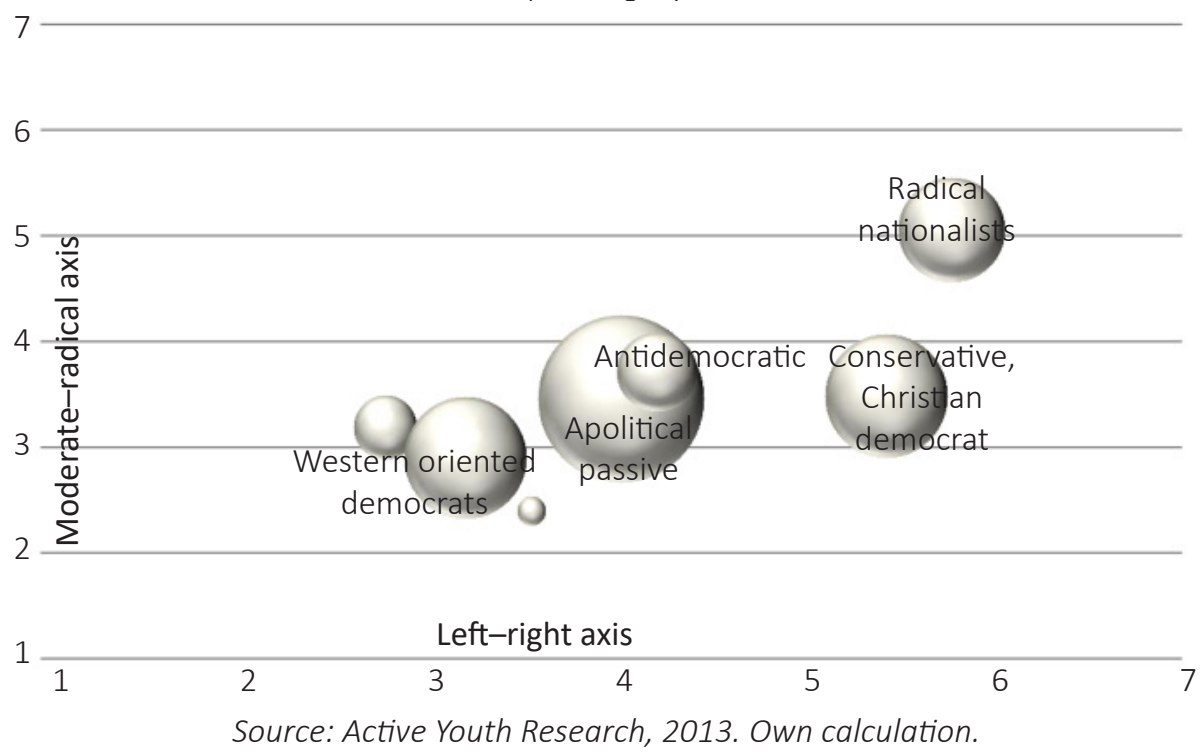

Figure 3. Hungarian university and college students cluster map on a Left-Right and Liberal-Conservative Scale (averages)

7

6

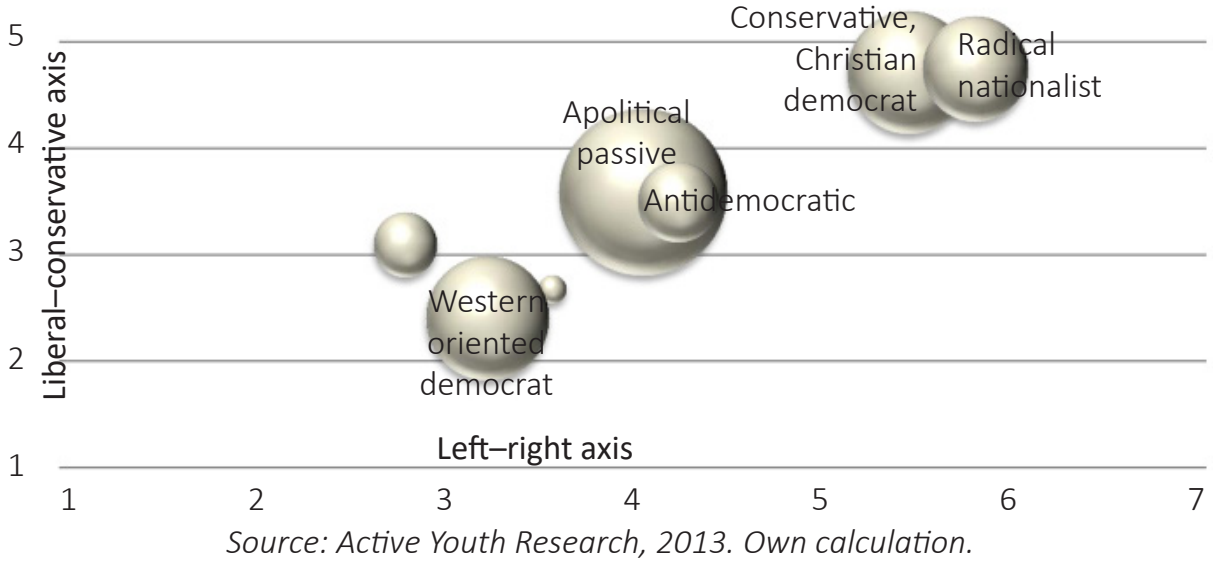

2. The members of the cluster called Antidemocratic are in favour of dictatorship (8\%), order and stability, but on the other hand they would not take part in an upcoming election this Sunday (see in the middle of Figure 2 and Figure 3 ). This means that the members of this cluster are very sceptical of the democratic system: they do not accept and do not want to legitimate the frameworks of the democratic system by taking part in elections.

3. The third cluster is the so called Western-oriented democrats (18\%) (see in the left corner of Figure 2 and Figure 3). In the question that prompted respondents to choose between Hungarian and Western values, those who ended up in this cluster markedly identified themselves with the latter. They are also strongly in favour of democracy, even though they are sceptical about the current democratic system. Their mindset is liberal and pro-European. They are interested in politics and in 
social problems. Based on their fathers' level of education, they can be characterized as coming from highly educated backgrounds, as urban dwellers and as atheists. This group is highly concentrated in Budapest and bigger cities. Their preferred method of political participation is Internet activity. They are overrepresented among students holding Master's and PhD degrees (therefore, among older students) and also among students majoring in the social sciences (economics, political science and the liberal arts).

4. Another cluster (the fourth) among full-time university students in Hungary is the cluster named Radical nationalists (14\%) after the Jobbik party ${ }^{7}$ (see in the right corner of Figure 2 and Figure 3). Members of this group are strongly nationalistic, radical, and denounce all forms of Western ideology. On the left-right scale, they strongly pull to the right. They believe "Gypsy-crime" is a fact and would, under certain circumstances, be willing to trade democracy for authoritarian rule. This is the sole cluster where gender plays an important role, given that the majority of this group consists of males. The cluster is formed by active individuals who make use of both traditional and virtual forms of political participation. They have lower average age: members are overrepresented among students pursuing a degree under the pre-Bologna system, among students pursuing Bachelor's degrees, as well as among those enrolled in computer science, engineering and liberal arts majors. The subjective financial situation of this group is somewhat worse. Most of them stem from families of lower or medium education (secondary or vocational school).

5. The fifth cluster has almost the same size as the second, and being a Conservative, Christian Democrat is the best predictor of this group, followed by three equally important traits: religion, being a Fidesz-voter, ${ }^{8}$ and satisfaction with the current democratic system (see in the right corner of Figure 2 and Figure 3). The members of this cluster are conservative, lean right, and are mostly active in traditional forms of political participation. It is important to note regarding this group that while they hold traditional values, they also deem democracy the best type of system. This group is overrepresented among degrees that are not split into undergraduate and master's studies, among them religious studies majors, legal studies majors, national defense majors, education majors and students pursuing advanced theological studies. In our survey, conservative students tended to be wealthier and better-off. Usually, their parents have university (or even doctoral) degrees. They are much more self-confident regarding their professional future and consider their career prospects to be more promising than those of other students.

6. The sixth and the seventh clusters are both very small. Both have a mainstream left-wing character, and both are related to Western-oriented democrats in several aspects.

7 Jobbik (Jobbik Magyarországért Mozgalom, Movement for a Better Hungary) is a radical right party, founded in 2003, and entered the Hungarian political mainstream in 2009 when they achieved 15 percent of the votes in the European Parliamentary elections.

8 Fidesz (Fiatal Demokraták Szövetsége, Alliance of Young Democrats) has been the government party of Hungary since 2010, led by Prime Minister Viktor Orbán. Fidesz is a conservative party, and a member of the European People's Party. 
Three competing political communities among the Hungarian youth

After the above-presented results of cluster analysis, politically active groups become identifiable in an analytical way. In our opinion, out of the seven clusters, three ideal types of young competing groups identity can be pinpointed, which were also described in the academic literature (Szabó A.-Kern 2011, Csözik 2012, Sörés-Róna 2012, Keil 2012, Szabó A. 2014). Thus, these competing political communities-basically subculture groups that provide lifestyle to young people-indirectly encourage participation. These groups have a voice that is understandable to the active sections of youth society. These active political groups are able to affect the entire youth; they can influence, organize and manage them. Two of the three active identity groups explicitly show a "rebellious" character and both these groups define their identity against the group that is currently in power, but from a completely different angle. The third group is also active, but does not take a stance against the government; rather, they support the actual government. However, some signs indicate that in the event of a fall from power of their favourite political party (Fidesz-KDNP), they were the most active, most rebellious group out of the three groups. This third political community is therefore currently not rebellious, but since its members are very active, this justifies the distinction.

\section{The right-wing activists}

First, we could distinguish a cluster which is based on the Conservative, Christian Democrat cluster, which we call "right-wing activists" (Szabó A.-Kern 2011, Kmetty 2014). ${ }^{9}$ This orientation consists of believers, because its members are religious, but also because they believe in the omnipotent character of elder members of the party and in their wisdom, almost unquestioningly. They identify themselves with the values of Fidesz without any criticism. This orientation is much more conformist in character than were the founders of the party; members of the cluster follow the road that has been built by the party leaders. In Debrecen, ${ }^{10}$ for instance, several participants of our focus group pointed out the overwhelming and one-sided effect they encountered: their teachers, parents, football-coach, priest and friends are all Fidesz voters. The main difference between this group and the green-left and radical rebel groups is that "right-wing activists" cannot be regarded as a movement. Besides the churchwhich is getting less and less popular among young people-there is no non-political (or half-political) pillar of their orientations. There are no bottom-up popular initiatives or organizations which would enhance the political values of conservatism among youngsters. Fidelitas and other Fidesz-youth platforms are top-down organizations which are not youth-oriented. To measure this empirically, we asked our respondents to describe each political party using the 11 descriptive adjectives and phrases provided. Only 16\% of those surveyed (and 47\% of Fideszvoters surveyed) said that Fidesz does a good job in appealing to youth, whereas Jobbik received this compliment from $36 \%$ of the respondents (and $67 \%$ of the Jobbik voters). This means that even Fidesz-supporter students do not tend to claim that Fidesz's strong suit is its appeal to youth. For many of the students, Fidesz is "old hat".

9 The Hungarian name is the "Tusványos" group. The authors named this section of the youth after its most important symbol. For them, solidarity with the Transylvanian Hungarians is essential: they are proud that it was the first Orbán government that granted double-citizenship to them. Tusványos is the name of the Transylvanian village where Fidesz organizes summer camps for young people every year and where Viktor Orbán gives a plenary speech about current political challenges facing the Hungarian nation. Mostly because of Orbán's annual speeches, the events have acquired a symbolic meaning. For instance, Orbán's (in)famous "illiberal democracy” speech took place at a Tusványos summer camp. 


\section{The Green-left "rebels"}

According to surveys conducted in several European countries, both highly qualified people and youths are more prone to support this party family (Dolezal 2010, Oesch-Rennwald 2010, Hooghe et al. 2010). Ecological inferences also confirm this tendency: the strongholds of green parties are in big cities, capitals, and especially downtown areas - places with a high proportion of young and educated inhabitants (Szabó 2013). Thus, university and colleges students are the "typical" supporter of green parties. This social group is too small to be analyzed in most survey samples; nonetheless, there are examples which corroborate this hypothesis (Dolezal 2010).

As for our results, the composition and characteristics of these "Western-oriented democrats" perfectly coincide with the youth group called "Green-new left rebels"11 by Szabó and Kern (2011). The characteristic values shared by the members of this group include: environmentalism, post-materialism, and revolt against the established elite. In accordance with European tendencies, the green movement appeals mostly to well-off young people in major cities. Members of the group tend to emanate from the ranks of those who have been called the "winners" of Hungary's democratic transition. This ideological group is detached from "traditional politics" and its members are searching for new values. According to Inglehart's framework (1997) these college and university students are characterized by post-materialistic values (Keil 2012). The party preferences of the green-new left rebels-compared with those of the two other groups-is not fully formed. Its members adapt to the ever-changing nature of the Hungarian party structure, when looking for those political elites that are close to them. During our research in 2011/2012, Politics Can Be Different (LMP) was the political party closest to them; in 2013 they preferred Együtt-PM, an alliance including the former prime minister Gordon Bajnai. Thus, members of the green-new left rebels members decided rationally about their party identification.

The rational and heavily Western-oriented nature of their participation is clearly demonstrated in several dimensions. Concerning the political activity of the green-new left rebels, the dominant element is, on the one hand, online participation and, on the other hand, direct forms of participation. It is a characteristic fact that its members were the largest cohort involved in protests that have been organized on the Internet (therefore online and direct forms of participation are linked in their case). Additionally, they get information through online media. It is no coincidence that these young people are the winners of the regime change. They are capable of transferring their advantageous background-a family with high cultural and financial capital-to their own "benefits". For example, they are those young people who study abroad or work abroad, and have experiences that enables them to work and even to establish themselves in the Western part of the world in the future. Another important aspect of their Western orientation is their ideological character. As noted above, green-new left rebels are ideologically atheist, open-minded, politically left or center-left oriented, with liberal and green ideology. Thus, the green-new left rebels have an anti-establishment nature in the sense that their way of life and thinking can be described with the new green-left ideology. Its members are the most tolerant toward minorities; it is the most inclusive group, having received this mentality either through multigenerational family socialization or during their studies in social sciences or humanities.

11 The Hungarian name is the Critical Mass political community. Critical Mass is the name of an urban bicycle parade that is held on the last Friday of each month worldwide in about 300 cities. In Budapest it is held in April on Earth Day and in September at the European mobility week and car-free Sunday. 
The Radical "rebels"

In some countries, young people are more likely to support this party family (Lubbers et al. 2002, Van der Brug et al. 2013: 62-63, Werts et al. 2013), but the correlation is robust only in Austria (Freedom Party of Austria, or FPÖ) and Hungary (Movement for a Better Hungary, Jobbik). Overall, there is no univocal tendency in Europe. As for qualification, according to conventional wisdom, the extreme right is more popular among the lowly educated, poor citizens ("modernization losers", Betz-Immerfall 1998, Kitschelt-McGann 1995). Recently, however, many scholars have challenged this holding, pointing out that there is no correlation whatsoever between level of education and far-right sympathy (Van der Brug et al. 2013, Bornschier-Kriesi 2013).

The second rebel political community, we call the "Radical rebels," as defined by Szabó and Kern (2011), since this group is exactly the same as that referred to in our K-Means cluster analysis as "Radical nationalist". ${ }^{12}$ We consider it a special group because the subculture-and based on that, the electorate of the extremist party Jobbik - has a generational background. The Internet and the grassroots level are the two strong strains of the radical subculture: they reach out to most newcomers using these two types of communication and mobilization.

Jobbik is not only popular among the young; according to a national representative sample of the Medián polling company and our university and college student sample, its popularity reaches the highest peaks in the cohort of those who are under 22 years old. The younger a person is, the more likely he/she would support the far-right party (see Rudas 2010, Bíró Nagy-Róna 2011, Kovács 2013). For that, the most compelling explanation is a cultural one (Róna-Sőrés 2012). According to this, students mainly join because they need a community that offers them identity and a distinct world view-and in the circumstances of many, Jobbik supplies these in unique proportion and manner. First of all, young citizens have the most freedom of availability and activity: they are preoccupied by relationships, work, or membership in civic organizations at a much lesser rate than earlier generations. This is, of course, true for all young people, but-according to the data-characterizes Jobbik supporters to a greater extent than those who are of the same age but vote for other parties. Demand meets supply: for those who want to do something there are not many alternatives (mainly in Eastern Hungary) besides the floundering political left and the "old hat", establishment embodied by Fidesz. Most respondents found Jobbik to be more active in their community than all the leftist parties combined. Jobbik puts considerable effort into addressing the youth: it organizes a variety of camps, professional events, protest and cultural programs prominently supported by "national rock" bands and other elements of the far-right subculture (for instance, organizations of material arts and folk traditionalists). Symbols are very important too: many students wear badges, t-shirts, bells with Árpád-stripes, Turuls,13 and maps of Greater Hungary. Internet sources-which are used primarily and most frequently by young people in Hungary-especially sites like kuruc.info, enhance the availability of Jobbik as well. To sum up, Jobbik offers precisely what youth voters need: world interpretation,

12 The Hungarian name of this group is "Kuruc.info". Kuruc.info is a news portal operated from the U.S. which provides space for extremist, xenophobic voices. The portal is the most read online news source among supporters of Jobbik. Its reach is broader than the number of regular student readers, extending throughout the far-right subculture. Kuruc.info is the unofficially preferred media outlet of Jobbik; it amplifies every component of the party's ideology. Many far-right supporters regard it as the only source of the "truth", which broadcasts "facts" hidden by the liberal and foreign-influenced media.

13 The Árpád-stripe is a flag which symbolizes ancient Hungary for radical right voters, but leftist citizens consider this as the symbol of the fascist and Nazi past of Hungary. The Turul (an eagle) similarly divides public opinion. 
identity, and a sense of belonging to a community.

\section{Conclusion}

In the introduction, we stated that former claims on political participation of young Hungarians are stereotypical, or at least do not hold true for the whole social group. After having carried out our analysis based on two approaches-participatory and phenomenological-the largest group was the group of politically passive students. Nearly 40 percent of students are uninterested in politics, have no political activity, and they find that the world of politics is too complicated. However-and this is the real novelty of our research-we found three demonstrable communities of roughly similar size. These groups show significant differences in political activity compared to the other groups. We consider these communities to be established gradually via socialization mechanisms after the regime change. They are not the results of a given political situation; they are rather "end products" of the transition process that started in 1990

Our analysis used two different approaches, since we found that former findings based on the participatory approach were not sufficient to describe the political activity of Hungarian college and university students.

The most important results of the normative approach are the following. Studying the three participation forms, one can establish that some of the more important predictors with significant explanatory value in predicting an individual's probability of lying in the active area include the student's family's socio-demographic background, sociocultural background, and certain individual competences. Male master's and PhD students are more likely to be "active" than their female counterparts. In terms of area of study, those studying social sciences and liberal arts are more likely to be active. The data suggest that the level of activity is partially determined by one's parents' own political activity and interest in public affairs/politics. This is shown by the significant correlation between the positive responses to questions related to the prevalence of political discussion with family members and friends and respondents' own level of political activity.

Politically active university students tend to position themselves at either end of the liberal/conservative and left/right spectrum instead of the middle. Active youth, on average, also tend to be significantly more radical than the rest of the student population. Some of these active youth identify themselves as conservative, strongly patriotic, and Christian Democratic, while others strongly identify with left-radical, Social Democratic, green, and environmentalist labels. Finally, it is important to note that while these active youth have varied party preferences, they-unlike the rest of the student population-have firmly decided whom they support and form part of the stable voting base of their respective political parties.

By using the phenomenological approach, we tried to find active groups of students that have an influence on political thinking and on the mobilization of different youth communities. We could detect seven clusters of students, and out of these, three active groups for analytical scrutiny. In the cluster analysis, we labeled the biggest groups as Western-oriented democrats (18\%) and we found another two small clusters (5 and 1\%) with less distinct characteristics. An ideal type (green-new left rebels) consists mostly of Western-oriented democrats. We identified the cluster named Radical nationalists (14\%), considered to belong to the "Radical 
rebel" political community, and we gave a detailed explanation of the characteristics of students belonging to this group. Finally, we identified the cluster of Conservative, Christian Democrats (17\%) that belongs to the "Right-wing activists" group. Our results have proved that active university and college students are not only ideologically engaged, but their party preferences are also expressed by their values and political sympathies.

We found that among Hungarian college and university students, there are three different political groups. If a given student is active, individual participation takes place within the framework of these groups. They show the characteristics of different political ideologies and "organize" different forms of political activity.

The group of Conservative, Christian Democrats is active, but it is a currently not a rebellious community, which is due to the fact that at present, their favourite political party is in power in Hungary. However, the other two political communities, the Western-oriented Green-left rebels and Radical rebels, act against the existing political power, and often organize spectacular, expressive activities. We conclude that the political way of thinking and the consequent political action may be determined by these three political communities in the long term. It is obviously important to consider how far these groups can survive in the political subsystem. During the period that has passed since the survey, some of the groups indicated in the text repeatedly made their voices heard in protests of varying size. However, in the absence of data, we cannot foretell whether or not a new, ideologically fragmented political generation is being formed. 


\section{REFERENCES}

Bauer B. - Szabó A. (2005) (eds.) Ifúúág2004. Gyorsjelentés. Budapest, Mobilitás.

Bauer B. - Szabó A.(2009) (eds.) Ifjúság2008. Gyorsjelentés. Budapest, Szociálpolitikai és Munkaügyi Intézet.

Betz H. G. - Immerfall S. (1998) The New Politics of the Right: Neo-Populist Parties and Movements in Established Democracies. St. Martin's Press, New York.

Bíró Nagy A. - Róna D. (2011) Tudatos radikalizmus. A Jobbik útja a Parlamentbe, 2003-2010. In Lánczi A. (ed.) Nemzet és radikalizmus. Századvég, Budapest, 242-283.

Bornschier, S. - Kriesi, H. (2013) The Populist Radical Right, the Working Class, and the Changing Face of Class Politics. In Rydgren, J. (ed.) Class Politics and the Radical Right. Oxon: Routledge.

Csákó M. (2004) Ifjúság és politika. Educatio, 2004/4, 535-550.

Csákó M. (2011) Állampolgárokat nevel-e az iskola? In Bauer B. - Szabó A. (eds.) (2011) Arctalan (?) nemzedék: Ifjúság $2000-2010$. Budapest, Nemzeti Család- és Szociálpolitikai Intézet, 101-114.

Dahlgren, P. (2000) The Internet and the democratization of civic culture. Political Communication, 335-340. https://doi.org/10.1080/10584600050178933

Dalton, R. J (2004) Democratic Challenges, Democratic Choices: The Erosion of Political Support in Advanced Industrial Democracies. Oxford University Press, UK.

Dalton, R. J. (2008) Citizenship Norms and the Expansion of Political Participation. Political Studies, 56(2), 76-98. https://doi. $\operatorname{org} / 10.1177 / 0020715215578488$

De Vreese, C. H. (2006) Political parties in dire straits? Consequences of national referendums for political parties. Party Politics, 12 (5), 581-598. https://doi.org/10.1177/1354068806066787

della Porta, D. - Tarrow, S. (ed.) (2005) Transnational Protest and Global Activism. New York, Rowman \& Littlefield Publishers, INC.

Dolezal, M. (2010) Exploring the Stabilization of a Political Force: The Social and Attitudinal Basis of Green Parties in the Age of Globalization. West European Politics, 33(3), 534-552. https://doi.org/10.1080/01402381003654569

Downs, A. (1957) An economic theory of democracy. New York, Harper \& Row.

Dunleavy, P. (1996) Democracy, Bureaucracy and Public Choice. Harvester-Wheatsheaf: Hemel Hempstead.

Henn, M. - Weinstein, M - Wring, D. (2002): A Generation Apart? Youth and Political Participation in Britain. The British Journal of Politics \& International Relations, 4 (2), 167-192. https://doi.org/10.1111/1467-856X.t01-1-00001

Hooghe, M. - Heyndels, B. - Jottier D. - Bircan, T. - Botterman, S. (2010) Explaining the Green vote: Belgian local elections, 19942006. Environmental Politics, 19(6), November 2010, 930-950. https://doi.org/10.1080/09644016.2010.518682

Inglehart, R. - Catterberg, G. (2002). Trends in Political action: The Developmental Trend and the Post-Honaymoon Decline. International Journal of Comparative Sociology, 43(2), 300-316. https://doi.org/10.1177/002071520204300305

Inglehart, R. (1997) Modernization and Postmodernization: Cultural, Economic and Political Change in 43 Societies. Princeton University Press, Princeton.

Keil, A. (2012) Adalékok a Critical Mass nemzedékről. Az egyetemista-főiskolás LMP szavazók jellemzése. In Szabó A. (ed.) Racionálisan lázadó hallgatók: Radikalizmus, posztmaterializmus, apátia. Szeged, Belvedere Meridionale.

Kern T. - Szabó A. (2011) A politikai közéleti részvétel alakulása Magyarországon, 2006-2010. In Tardos R. - Enyedi Zs. - Szabó A. (eds.) Részvétel, képviselet, politikai változás. Budapest, DKMKA.

Kitschelt, H. - McGann, A. J. (1995) The Radical Right in Western Europe. A Comparative Analysis. University of Michigan Press, Ann Arbor.

Klingemann, H. D. - Fuchs, D. (1995) Citizens and the State. Oxford: Oxford University Press.

Kmetty Z. (2014) Fiatal, vallásos és fidesze. In Szabó A. (ed.) Racionálisan lázadó hallgatók II. Apátia - radikalizmus - posztmaterializmus a magyar egyetemisták és föiskolások körében. Budapest - Szeged, Belvedere Meridionale - MTA PTI, 173-186.

Kovács, A. (2013) The Post-Communist Extreme Right: The Jobbik party in Hungary. In Wodak R. - Khosravi N. M. - Mral, B. (eds.) Right-Wing Populism in Europe. Politcs and Discourse. Bloomsbury, London, 223-235.

Kriesi, H. (2008) Political Mobilization, Political Participation and the Power of the Vote. West European Politics, 31 (1), $147-168$. https://doi.org/10.1080/01402380701834762

Laki L. - Szabó A. (2014) Mi lehet a magyar fiatalok demokráciaszkepszise mögött? In Szabó A (ed.) Racionálisan lázadó hallgatók II. Apátia - Radikalizmus - Posztmaterializmus a magyar egyetemisták és föiskolások körében. Belvedere Meridionale - MTA TK PTI, Budapest - Szeged, 18-42. 
Livingstone, S. - Bober M. - Hesper, E. (2005) Active participation or just more information? Young people's take-up of opportunities to act and interaction the Internet. Information, Communication and Society, 8(3), 287-314. https://doi.org/10.1080/13691180500259103

Lubbers, M. - Mérove, G. - Scheepers, P. (2002) Extreme Right Wing Voting in Western Europe. European Journal of Political Research, 41 (3), 345-78. https://doi.org/10.1111/1475-6765.00015

McAdam, D. - McCarth, J. D. - Zald, M.N. (eds.) (1996) Comparative Perspectives on Social Movements: Political Opportunities, Mobilizing Structures, and Cultural Framings. New York, Cambridge University Press.

Niemi R. G. - Hepburn M. A. (1995) The rebirth of Political Socialization. Perspectives on Political Science, 24 (1), 7-16. https://doi.org/10.1080/10457097.1995.9941860

Norris, P. (2002). Democratic Phoenix. Reinventing Political Activism. Cambridge, Cambridge University Press.

Norris, P. - Curtice, J. (2008) Getting the Message Out: A two-step model of the role of the Internet in campaign communication flows during the 2005 British General Election. Journal of Information Technology and Politics, 4(4) 3-13. https://doi.org/10.1080/19331680801975359

Oesch, D. - Rennwald, L. (2010): The Class Basis of Switzerland's Cleavage between the New Left and the Populist Right. Swiss Political Science Review, 16(3), 343-372 https://doi.org/10.1111/spsr.12188

Oross, D. (2013) Társadalmi közérzet, politikához való viszony In Székely L. (ed.) Magyar Ifjúság 2012: tanulmánykötet. Budapest: Kutatópont Kft., 283-315.

O'Toole, T. - Lister, M. - Marsh, D. S. - Jones, S. - McDonagh, A. (2003) Tuning out or left out? Participation and non-participation among young people. Contemporary Politics, 9 (1), 45-61. https://doi.org/10.1080/1356977032000072477

Pattie, C. - Seyd, P. - Whiteley, P. (2004) Citizenship in Britain: values, participation and democracy. Cambridge: Cambridge University Press.

Phelps, E. (2004) Young Citizens and Changing Electoral Turnout, 1964-2001. The Political Quarterly, 75 (3), 238-248. https://doi.org/10.1111/j.1467-923X.2004.00608.x

Róna D. - Sőrés A. (2012) A kuruc.info nemzedék. Miért népszerú a Jobbik a fiatalok között? In Szabó A. (ed.) Racionálisan lázadó hallgatók. Radikalizmus, posztamterializmus, apátia a magyar egyetemisták és föiskolások körében. Belvedere, Szeged, 113-157.

Rudas, T. (2010) A Jobbik törzsszavazóiról. In Kolosi T. - Tóth I. Gy. (eds.) Társadalmi Riport 2010. Budapest, Tárki.

Szabó, A.- Bauer B. - Laki, L. (eds.) (2002) Ifjúság2000, Tanulmányok I. kötet. Budapest, Nemzeti Ifjúságkutató Intézet.

Szabó, A. (ed.) (2013) Political Orientations, Values and Activities of Hungarian University and College Students. Prague: Heinrich Böll Stiftung.

Szabó A. (2014a) Előszó. In Szabó A. (ed.) Racionálisan lázadó hallgatók II. Apátia - radikalizmus - posztmaterializmus a magyar egyetemisták és föiskolások körében. Budapest-Szeged, Belvedere Meridionale - MTA PTI, 9-14.

Szabó A. (2014b) Zárszó helyett. A magyar nappali tagozatos egyetemi és főiskolai hallgatók politikussága. In Szabó A. (ed.) Racionálisan lázadó hallgatók II. Apátia - radikalizmus - posztmaterializmus a magyar egyetemisták és föiskolások körében. BudapestSzeged, Belvedere Meridionale - MTA PTI, 257-270.

Szabó A. - Kern T. (2011) A magyar fiatalok politikai aktivitása. In Szabó A. - Bauer B. (eds.) Arctalan (?) Nemzedék. Budapest, Nemzeti Család- és Szociálpolitikai Intézet.

Szabó A. - Oross D. (2012) A demokratikus részvétel tendenciái a magyar egyetemisták és főiskolások körében. In Szabó Andrea (ed.) Racionálisan lázadó hallgatók. Szeged, Belvedere Meridionale, 65-111.

Szabó, B. (2013) Az új parlamenti pártok szavazóbázisának jellemzői Budapest példáján. Politikatudományi Szemle, XXII/3, 92-116.

Szabó I. (1994) Minden másképpen van. Politikai reszocializáció Magyarországon. Világosság, 1994 (3), 61-73.

Szabó, I. (2000) A pártállam gyermekei. Budapest, Új Mandátum Könyvkiadó.

Szabó, M. (2007) A tiltakozás kultúrája Magyarországon. Társadalmi és politikai tiltakozás 2. Budapest, Rejtjel Politológia Könyvek.

Szabó, M. (2008) Globális kommunikáció, civil társadalom, tiltakozás. Fordulat, 2008 (1).

Utasi, Á. (2010) Közösségi kapcsolatok. Múhelytanulmányok III. Szeged, Belvedere.

Van der Brug, W. - Fennema, M. - de Lange, S.- Baller, I. (2013) Radical Right Parties: Their Voters and Their Electoral Competitors. In Rydgren, J. (ed.) Class Politics and the Radical Right. Oxon: Routledge.

Verba, S. - Schlozman, K. L. - Brady, H. E. (1995) Voice and Equality. Civic Voluntarism in American Politics. Cambridge: Harvard University Press. 
Werts, H. - Scheepers, P. - Lubbers, M. (2013) Euro-scepticism and radical right-wing voting in Europe, 2002-2008: Social cleavages, socio-political attitudes and contextual characteristics determining voting for the radical right. European Union Politics, 14(2) 183-205. https://doi.org/10.1177/1465116512469287

Williams, R. H. (1995) Constructing the Public Good: Social Movements and Cultural Resources. Social Problems, (42), $124-144$.

Williams, R. H. (2004) The cultural Contexts of Collective Action: Constraints, Opportunities, and the Symbolic Life of Social Movements. In Snow, D. A. - Soule, S. A. - Kriesi, H. (eds.) The Blackwell Companion to Social Movements. Oxford, Blackwell Publishing Ltd.

Zukin, C.- K. - Scott , A. - Molly J. - Delli Carpini, K. - Michael (2006) A New Engagement? Political Participation, Civic Life, and the Changing American Citizen. New York, Oxford University Press. 